stitution of felspar, or if, indeed, its true nature can be represented by such formulæ, is a question which Kolbe leaves untouched, for the simple reason that the necessary experimental foundation from which alone valid arguments can be drawn, is entirely wanting.

Professor Kolbe concludes this remarkable paper by defining what should be the future aim of the student in Mineralogical Chemistry. He must not now rest content with a mere quantitative analysis, or with the empirical deduction of rational formulæ from the results of such analysis. Such a process can never fully elucidate the chemical constitution of inorganic compounds. This can only be accomplished by a careful and systematic study of the decomposition, syntheses, and substitutions; in other words, by the application of methods of research similar to those which have yielded such splendid results in Organic Chemistry.

T. E. THORPE

\section{NEW OBSERVATORY IN THE SOUTHERN HEMISPHERE}

THE following statement with regard to the Cordova Observatory, to the foundation of which we have before referred, is extracted from the last number of Silliman's American Fournal of Science and Arts.

"The Argentine Congress voted to establish a national observatory at Cordova, at the instance of President Sarmiento, and through the exertions of the present Minister of Public Instruction, Dr. Avelleneda, who invited me to organise and take charge of it, knowing my desire to extend the catalogue of the southern heavens beyond the limit of $30^{\circ}$ to which the zones of Argelander extend. Bessel went through the region from $45^{\circ} \mathrm{N}$. to $15^{\circ} \mathrm{S}$. with systematic zone observations at Königsberg, which have since been reduced and published in two catalogues by Weisse of Cracow. Argelander carried the same systematic scrutiny with the Meridian Circle, from Bessel's Northern limit to the pole, and afterwards from Bessel's Southern limit to $30^{\circ} \mathrm{S}$.

"Since then Gilliss has observed a series of zones for $30^{\circ}$ around the south pole; but the reduction of these, although very far advanced, was not completed at the time of his death, and the MS. is now stored somewhere in Washington. Let us hope that it may at some time be recovered, the work completed and given to the world.

"My hope and aim is to begin a few degrees north of Argelander's southern limit, say at $26^{\circ}$ or $27^{\circ}$, and to carry southward a system of zone observations to some declination beyond Gilliss's northern limit, thus rendering comparisons easy with both these other labours, and permitting the easy determination of the corrections needful for reducing positions of any one of the three series to corresponding ones for the other. It is of course impossible to arrange in advance the details of such an undertaking, but my expectation is to go over the region in question in zones $2^{\circ}$ wide (except in the vicinity of the Milky Way where the width would be but one-half as great), up to a declination of about $55^{\circ}$, after which the width would be gradually increased as the declinations became greater. Within these zones all stars seen as bright as the gth magnitude would be observed, so far as possible, moving the telescope in altitude when no bright star is in the field until some one becomes visible, according to the well known method of zone-observations.

"For reducing the observations, differential methods will probably be employed, inasmuch as the time now assigned for my absence from home would be inadequate for proper discussion of the correction required for nice determinations of an absolute character. Still, it is my present purpose, so far as possible, to make such subsidiary determinations as might hereafter be needed in any attempt at computing the observations absolutely. But as I hardly venture to anticipate any opportunity of making a thorough determination of the constants of refraction, or of the errors of graduation, it seems best to arrange for a differential computation at least at first.

"It is improbable that a sufficient number of well-determined stars will be found available even for this differential reduction, and the necessity may thus be entailed of determining the comparison-stars myself, this determination, however, itself depending upon standard star places. So far as possible I propose employing those heretofore cletermined by me, and published by the Coast Survey, which form the basis of the star places of the American Nautical Almanac.

"With these observations of position it is my hope to combine others of a physical character to some extent; but in the presence of a plan implying so much labour and effort, it would be unwise to rely upon the possibility of accomplishing much more than the zone-work.

"The meteorological relations of the place are very peculiar, but I dare not undertake any connected series of observations bearing upon these, without self-registering apparatus, which is beyond my means.

"Cordova is one of the oldest cities, and contains the oldest university, of the Western hemisphere. It is situated in $31_{\frac{1}{2}}^{\circ} \mathrm{S}$. latitude, on the boundary of the Pampa, where the land begins to rise toward the group of mountains known as the Sierra de Cordova. It is connected with Rosario, on the Parana, by the Central Argentine Railway, which has probably been already opened to travel through its entire iength of about 250 miles, although information to that effect has not yet reached this country.

"The two largest instruments will be a Repsold meridiancircle of 54 inches focal length and $4 \frac{1}{2}$ inches aperture, and an equatorial by Alvan Clark and Sons, provided with the Ir-inch object-glass, by Fitz, lately in the possession of W. Rutherfurd, who has supplied its place by one of 13 inches. A photometer by Ausfeld of Gotha, according to Zollner's latest form, has been constructed under the supervision of Prof. Zölner himself; a spectroscope will be furnished by Merz of Munich, and a clock by Tiede of Berlin.

"The Scientific institutions of the U.S. have afforded the expedition every possible assistance. The Coast Survey lends a circuit-breaking clock, a chronograph, and a portable transit; the Smithsonian Institution lends a zenith telescope; the American Academy of Arts and Sciences of Boston (probably) a photometer and spectroscope; the Washington Observatory and the Nautical Almanac have greatly aided the undertaking by gifts of books and by a manuscript copy of Gilliss's catalogue of Standard Stars ; and from the astronomers of England, Germany, and Russia important assistance has been freely and effectirely contributed, in the order and supervision of instruments and apparatus, and by the gift of books, as well as by important and valuable suggestions.

"Four assistants will accompany me, Messrs. Miles Rock, John M. Thome, Clarence L. Hathaway, and Williain M. Davis, jun. We hope to reach Buenos Ayres not later than the middle of August.

"The building is now under construction in Boston. The means available proved inadequate for its construction according to the original plan, which was in the form of a cross, with four square rooms about its centre, and turrets at its four extremities. One half of it will be first erected, and it is hoped that the remaining portion will speedily be added."

B. A. GOULD

\section{SCIENTIFIC SERIALS}

THE greater part of the Revue des Cours Scientifuncs for July 23 , is occupied by the commencement of a very able paper read before the Anthropological Society of Paris by Prof. Broca, on the Transformation of Species. Commencing with the preDarwinian theories of transformation of Blainville and Lamarck, he then proceeds to give a résumé of the theory of Darwin, and 
the arguments in favour of or agrainst the permanence of species, drawn from the observation of living species and from palæontology. Following this we have, $a$ propos of the war, an article on field ambulances and hospitals, by Prof. Champouillon. In the number for July 30 , we bave the rectorial address of von Littrow to the University of Vienna, on the backward state of science among the ancients, and the conclusion of M. Broca's faper on the transformation of species, in which the subject is treated from a philosophical point of view, and the professor sums up strongly against the idea of permanence. The hypothesis of Natural Selection is then discussed, but a much less certain conclusion arrived at. The number for August 6 opens with a report of the cliscussion on the nomination of Mr. Darwin as corresponding member of the Academy of Sciences, to which we have referred in another column. This is followed by a singularly able and exhaustive review by $M$. Claparède, of Geneva, of Mr. A. R. Wallace's Essays on Natural Selection, in which he points out that while Mr. Wallace demands the intervention of a superior force to explain the foundation of the human races, and to guide man in the path of civilisation, he altogether denies the existence of such a force as assisting to produce the inferior races of animals and plants, which he attributes entirely to the operation of Natural Selection. In the same remarkably interesting number of the Revue, we have also Mr. Marey's extremely important paper on the Flight of Birds.

THE current number (No. xxxix.) of the Quarterly Fournal of Microscopic Science is an unusually rich one, containing several papers of great importance. Amongst them we maydraw attention to one of considerable length by Dr. Beale, entitled "Bioplasm, and its degradation," with Observations on the Origin of Contagious Disease. He introduces and defends the use of the term Bioplasm, which we think is admissible enough, and serves very well as a distinguishing appellative for actually living matter, as opposed to protoplasm, which has been rather vaguely used to designate organic matter whether dead or alive. The application, however, of the new term is sufficiently wide, since Dr. Beale appears to consider them in a special form for each separate structure in the body originating in the primary mass of bioplasm of the egg. From each subdivision of the latter "in pre-ordained order, and with perfect regularity more are produced, no doubt according to laws, but laws which we know nothing about, except that they are not physical." This last assertion indeed seems open to question, for if we know nothing about them, how can it be saicl with certainty that they are not physical, as it is certain we are not acquainted with all the physical laws of the world. Dr. Beale proceeds to describe the Bioplasm of the Amœba, the principal forms of that of man, and its relations to such morbid products as pus and infectious poisons. An interesting paper follows, by Dr. Macdonald, of H.M.S. Fisgard, on the minute anatomy of some of the parts concerned in the function of accommodation to distance. Dr. Caton describes the means he has found best adapted for studying transparent vascular tissues in living animals. To this succeeds a capital részumé of Prof. Stricker's "Studien aus der Institut für experimentelle Pathologie in Wien ans dem Yahre 1869," and the part devoted to original communications terminates with two essays, one by Mr. E. Ray Lankester, on the Migration of Cells, and one by A. M. Edwards, on Diatomacee.

The Transactions of the Linnean Sociely, vol. xxvi., pt. 4, is entirely occupied by two papers on Fossil Cycads. The first, by Prof. W. C. Williamson, is descriptive of the remarkable Zamia gigas Lindl. and Hutton, or Williamsonia gigas Carr., found in considerable abundance in the Lias at Whitby. He believes it to have borne a strong resemblance to existing Cycads with diocions flowers. In Mr. Carruthers's valuable monograph of Fossil Cycadean stems from the Seconciary rocks of Britain, he shows that these fossils are, as far as is at present known, entirely confined to Secondary strata, the so-called Cycadea of the coalmeasures and other palæozoic strata being rather referable to cryptogamic Letidodendra, and the few specimens reported from Miocene beds being very imperfect and uncertain. In his description which follows, Mr. Carruthers describes four new genera from British rocks, Yatesia, Fittonia, Williamsonia, and Bennetzites. Both papers are illustrated by excellent plates. - Vol. xxvii., part 2, is of more varied interest. Mr. John Miers contributes two botanical papers; a description of three new genera of Verbenacee, Rhaphithamnus, Fhelloderma, and Diostea, from Chile and the adjacent regions; and a paper on the anomalous genera
Gatzia and Esfadea, the position of which is very unsettled, and which he proposes forming into a new order. Dr. Birdwood describes and figures three new species of Bosztellia, natives of the Soumali country, all of which yield frankincense, and one of them, he believes, the bulk of the olibanum of commerce. Dr. J. B. Hicks points out a singular resemblance between the genus Draparnaldia, and the confervoid filaments of mosses. We have descriptions of new Agarics and Lichens from Ceylon, the former by the Rev. M. J. Berkeley, the latter collected by Mr. Thwaites, and named by the Rev. W. A. Leighton, who also contributes notes on the Lichens of St. Helena, and a description of a new British Fungus, Sphacria tartaricola, Nyl. The longest paper in this part is an important monograph by Messrs. Henry Brady, Parker, and T. Rupert Jones, of the genus Polymorphina, an attempt to rescue this difficult genus of Foraminifera from the almost inextricable confusion into which it has fallen. Dr. A. Rattray contributes a paper on the anatomy, physiology, and distribution of the Firolide, forming the section of Heteropoda with a straight and elongated form, and either wholly naked or furnished with a very small shell, and including the genera Carinaria, Carinaroides, Firola, and Firoloides. Sir John Lubbock proceeds with his Notes on Thysantura, part iv. ; and from Dr. Edward Moss we have an account of the genus Appendicularia, with its remarkable appendage, or "haus," the object of which in the vital economy has not been ascertained.

\section{SOCIETIES AND ACADEMIES}

LONDON

Entomological Society, July 4.-Mr. Alfred R. Wallace, president, in the chair. The Rev. F. A. Walker and Mr. Edward Mackenzie Seaton were elected members. Numerous objects of interest were exhibited by or on behalf of Mr. Meek, the Hon. T. De Grey, Mr. F. Moore, Mr. Blackmoor, Mr. Albert Muiller, Mr. Jenner Weir, Sir J. C. Jervoise, Bart., Mr. Tegetmeier, and others.-Prof. Westwood made some ubservations on a group of very minute four-legged Acari, and the Presic'ent mentioned instances of protective mimicry in insects, recently observed by Mr. Everitt in Bornen.-The following papers were read:-- "Further observations on the Relation Eetween the Colour and the Edibility of Lepidoptera and their Larva," by Mr. J. Jenner Weir ; "On a Collection of butterflies, sent by Mr. Ansell from South-Western Africa," by Mr. A. G. Butler; "Contributions to the Insect Fauna of the Amazons" (continuation, Colecptera longicornia, Fam. Cerambycidce), by Mr. H. W. Bates; "List of the Hynnenoptera captured by Mr. J. K. Lord in Egypt and Arabia, with Descriptions of New Species," by Mr. Francis Walker.

\section{EDINBURGH}

Scottish Meteorological Society, July 21. - Half-yearly general meeting, Mr. Milne Home in the chair. The following report from the Council was read :- "The Council have to report that the number of the Society's stations is now ninety-one, there being an addition of one since the last general meeting, in consequence of the services of an observer having been obtained for Leith. At the last half-yearly general meeting, reference was made to a renewed application by the Council to Government for pecuniary aid. 'i he application was so far favourably received that the Board of Trade a second time recommended the Council to prefer to the committee of the Royal Society their claim, with a view to an allowance being made from the annual Parliamentary grant of $10,000 \%$. for meteorological purposes, of which grant that committee have charge. The Council regret to say that the Royal Society committee have stated that they are unable tn make or promise any allowance out of the grant, as the whole of it has been appropriated to other objects; for which objects the grant is, as the committee state, even too small in amount. The Council have in these circumstances been induced to renew their application to Government for a special grant to the Society. The Council have requested Mr. Buchan to prepare a report on the monthly temperature of the British islands, and to state to this meeting a few of the results obtained by him. The subject is one which it is believed has not been thoroughly investigated by any other society, or indeed by any meteorologist except Professor Dove; and Professor Dove's charts, which are now ten years old, were based on observations not only necessarily scanty, but in several cases unavoidably incorrect. The first chart which this Society prepared of the 